\title{
Tissue Changes of the Periodontium in a Periodontal Patient as a Result of Orthodontic Treatment
}

\author{
Alexander Koval ${ }^{1}$, Eva Koval'ová*1, Tatiana Klamárová ${ }^{1}$ and Eleonóra Ivančová ${ }^{2}$ \\ ${ }^{1}$ Faculty of Health, University Presov in Prešov, Slovak Republic \\ ${ }^{2}$ Faculty of Dentistry UPJŠ, Košice, Slovak Republic
}

*Corresponding author: Eva Kovalová, Faculty of Health, University Presov in Prešov, Slovak Republic

\section{ARTICLE INFO}

Received: 慧 July 03, 2020

Published: 幽 July 10, 2020

Citation: Alexander K, Eva K, Tatiana K, Eleonóra I. Tissue Changes of the Periodontium in a Periodontal Patient as a Result of Orthodontic Treatment. Biomed J Sci \& Tech Res 28(5)-2020. BJSTR. MS.ID.004708.

\author{
ABSTRACT
}

The basic role of intraalveolar ligaments in the periodontal cleft is to hold the tooth in the dental bed and to dampen the force of pressure during the bite, chewing and transmit it evenly to the whole bone. With the long-term action of certain forces, the intraalveolar ligaments are rebuilt. Teeth change position due to treatment, during incision, growth, tongue pressure, muscle, antagonists and adjacent teeth. When applied force is applied to a tooth, it is transmitted to the ligament in the periodontal cleft and to the alveolar bone. The area where the pressure is transmitted to the alveolar bone is called the "pressure zone". The zone where the force acts on the ligament in the periodontal cleft by pulling is called the "pull zone". These forces can be used in maxillofacial therapy in periodontal patients.

Keywords: Periodontitis; Orthodontics; Cooperation; Quality Of Care; treatment. Clinical cases

\section{Introduction}

Tissue changes in the pressure zone. The tissues in the pressure zone react differently depending on the magnitude of the applied force. If the applied force is too small, it will not cause any changes in the ligament in the periodontal cleft or in the position of the teeth. However, if the force is above the threshold but does not limit the blood supply, these changes will occur [1]. The following situations may occur:Hyperemia in the connective tissue in the periodontal cleft, proliferation of cells, osteoclasts appear in the alveolar bone, which cause bone resorption. Howship's lacquers, there can be a rapid reorganization of the periodontal fibers in the periodontal cleft, which allows to maintain the function of the teeth and the constant renewal of the intraalveolar fibers, despite the bone breakdown in the pressure zone, which still continues. On the alveoli, apposition occurs towards spongiosis, thus the strength of the alveolar bone layer is maintained with the progressive resorption by the periodontal cleft. By the application of spongiosis and the resorption of the fibrous fibers, the alveolar bone is displaced, thus allowing the desired displacement of the teeth[2,3].

Direct resorption: a condition in which alveolar bone is resorbed directly from the periodontal cleft. If the force applied is too great or concentrated on a small area of the periodontal cleft, circulatory interruption and ischemia may occur. Thus, the cells disappear in this area and the collagen fibers disintegrate partially. From a histological point of view, this part turns pink [1,2]. This is called hyalinization. Due to the disappearance of cells, alveolar resorption is not possible. By accurately measuring the movement of the teeth, it is possible to find that in these cases the movement of the teeth stopped after the periodontium was depressed. Nevertheless, the movement of the teeth resumes within 2, 3 weeks [4-6].

Indirect resorption is a condition in which a layer of alveolar bone is resorbed from the cancellous side. Indirect resorption and hyalinized areas are very common at the beginning of orthodontic treatment. They most often occur when the teeth are bent and the pressure is concentrated in a narrow area of the periodontal cleft near the alveolar ridge $[4,5]$. Upon completion of indirect resorption, the structure of the fibrous fibers re-normalizes and thus returns to its original state. However, when the force is increased again, the indirect resorption may be repeated. The surface of the alveolar ridge is another site that is subject to changes in the pressure zone. Below the periosteum, bone apposition occurs. On the cancellous 
side of the alveolar cortex, resorption occurs in such a way that the compact is gradually rearranged and the same time displaced in the direction of tooth movement. This mechanism ensures the movement of the alveolar protrusion together with the tooth, even with extensive changes in the position of the teeth [2,5].

\section{Casuistic}

A 28-year-old patient was referred to us by his dentist with a request for a periodontal examination. Based on a complete examination, we determined the diagnosis and proposed alternatives to the treatment plan, which consists of four phases: preparatory, hygienic, definitive and maintenance phase [4-7]. In the preparatory phase, we performed a comprehensive examination of the patient. The patient completed an anamnestic questionnaire.
We performed an extraoral examination of the patient. We found facial asymmetry caused by a jaw-orthopedic anomaly. We continued the patient's intraoral examination. We examined the condition of the teeth, the condition of hygiene (KOD - 75), the condition of the mucogingival area (stroke of the frenulum labii superioris, width of the attached gingiva in the lower front $2 \mathrm{~mm}$, present gingival recesses), condition of the periodontium (CPITN 4-4-4 / 4-4- 4, activity of a purulent exudation sac $\mathrm{dN}^{\circ} 21,46,36$, $16,26)$ and mucosal status (no pathological findings). We also took $\mathrm{X}$-rays (OPG, intraoral images). Based on this, we determined the diagnosis (periodontologically active (P3 aggressive periodontitis generalized form, RP3 - RP4 and jaw-orthopedic anomaly) (Figures 1-9).

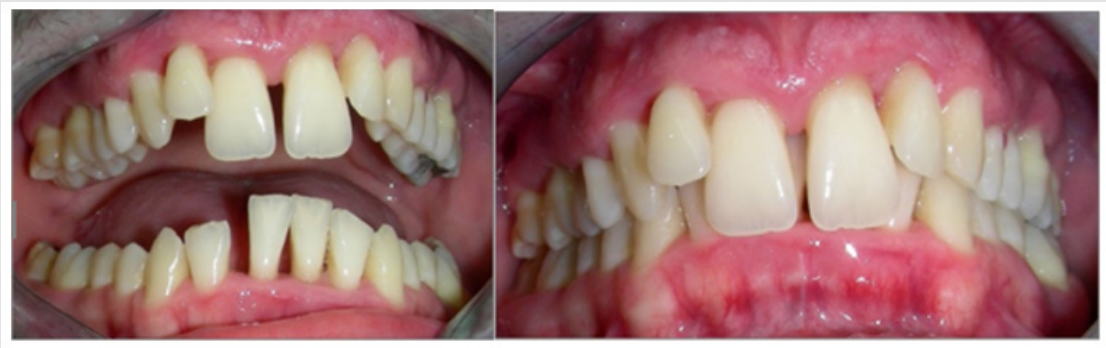

Figure 1

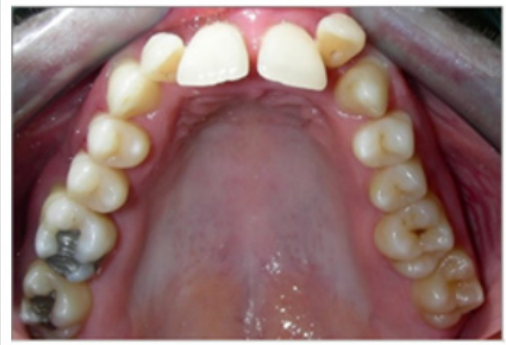

Figure 3
Figure 2

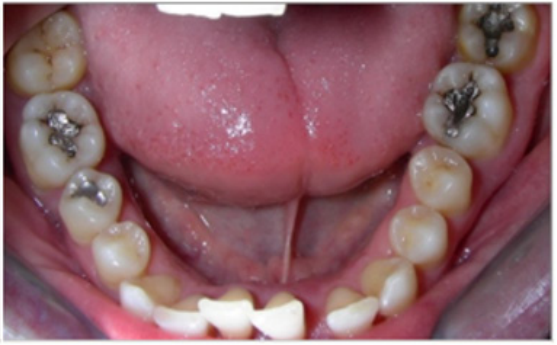

Figure 4

Figure 1-4: Patient's condition at the first visit, November 2017.

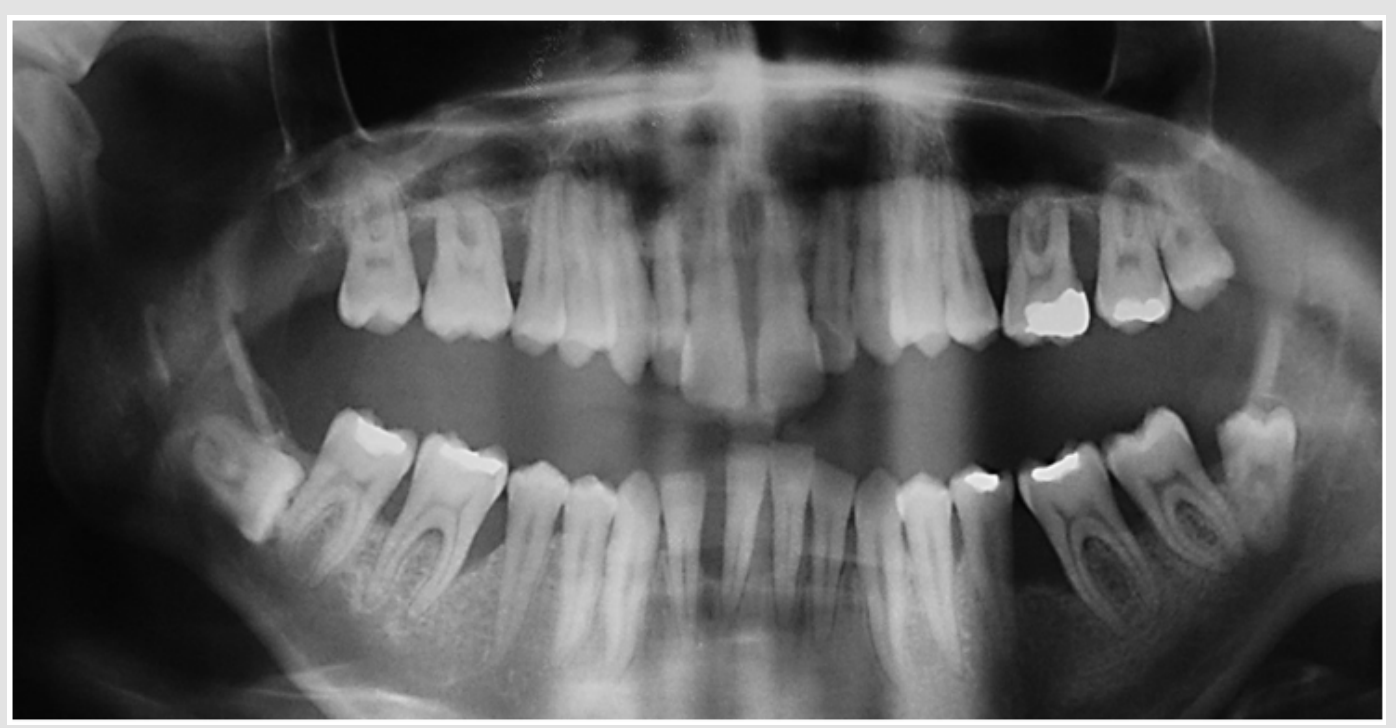

Figure 5: Extraoral X-ray, November 2017. 


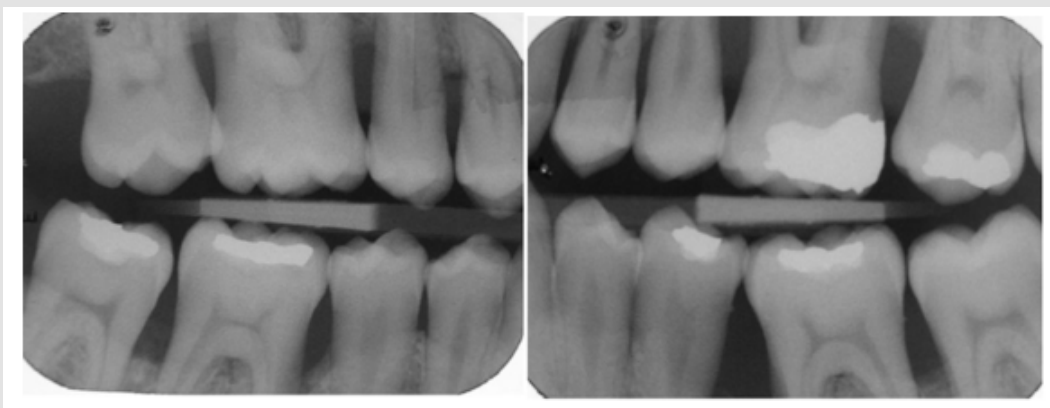

Figure 6

Figure 7

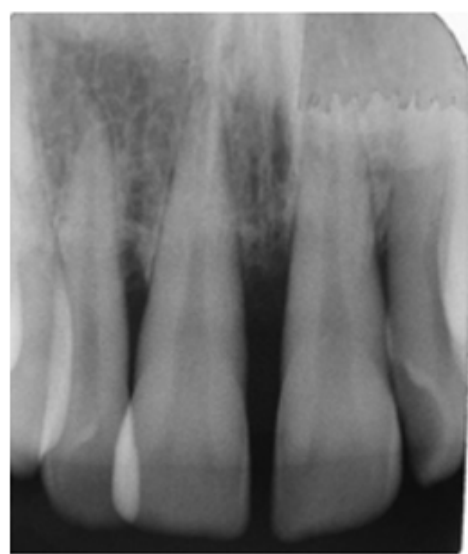

Figure 8

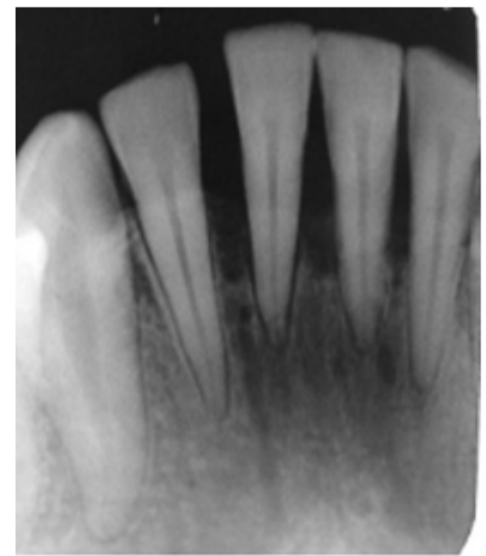

Figure 9

Figure 6-9: Extraoral X-ray, November 2017.
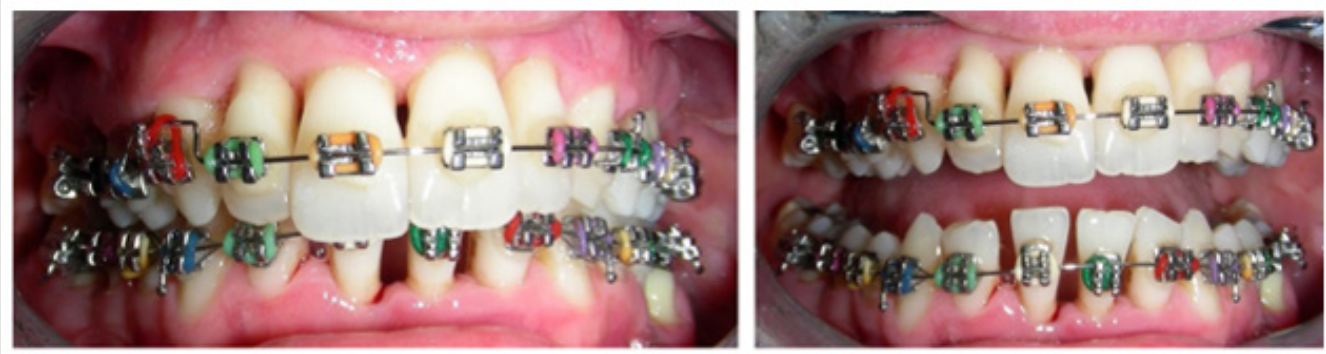

Figure 10

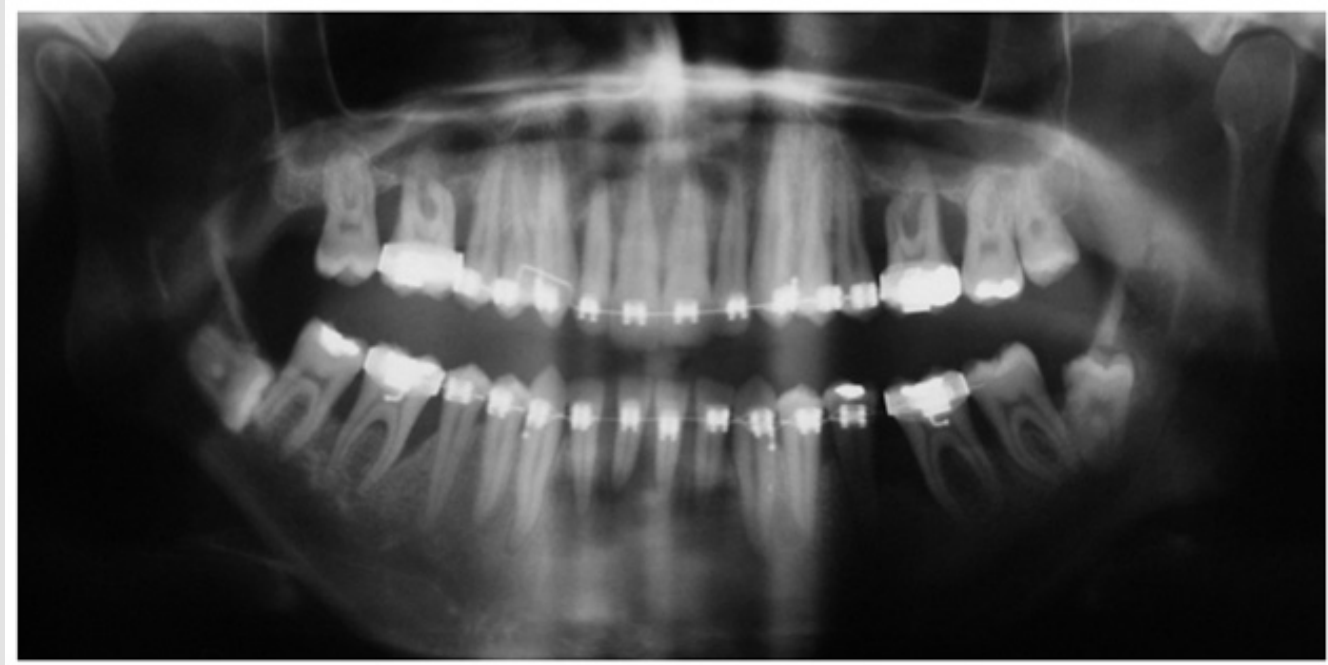

Figure 10 \& 11: Fixed apparatus, OPG during fixed apparatus treatment. 
We have prepared suggestions for possible treatment procedures for the patient, their time and financial costs. In the hygienic phase, in cooperation with a dental hygienist, we started the treatment of the periodontium. In the first visit of the hygienic phase, we motivated and instructed the patient (Bass tooth cleaning technique, interdental brushes for interdental spaces and periodontal cams). We performed a complete periodontal treatment. The periodontal cams were rinsed with chlorhexidine solution. We recommended that the patient apply chlorhexidine gel to the periodontal sacs for 14 days. We prescribed antibiotic treatment, a combination of Augmentin (2x1g for 10 days) and Entizol (3x400 mg for 10 days). After 6 weeks from the last visit in the hygienic phase, we re-evaluated the patient's condition. We reevaluated his cooperation and the reaction of the teeth and tissues of the periodontium to the performed treatment. The condition of the periodontium was without purulent exudation, without inflammatory activity. We planned the periodontal condition check in the first year of periodontitis treatment every 2 months. In the final phase, we implemented a treatment plan. We performed a surgical procedure - upper frenulolectomy. Subsequently, we solved the jaw-orthopedic anomaly. In March 2018, the patient was given a fixed apparatus for upper and lower dentures (Figures 10-11).

During orthodontic treatment, the patient went for regular dental hygiene to check the condition of the periodontium. In March 2020, we removed the fixed apparatus. After removing the fixed appliance, we elongated our teeth and re-evaluated the patient's condition. We took X-rays (Figures 12-22).

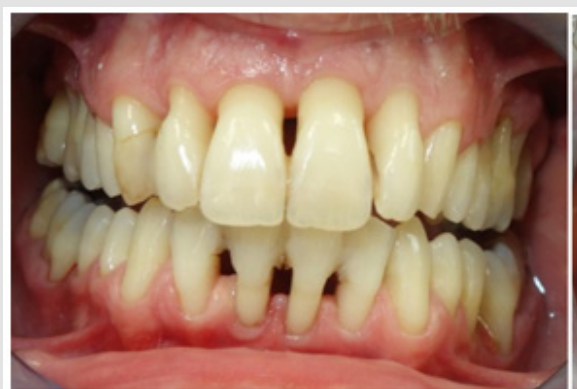

Figure 12

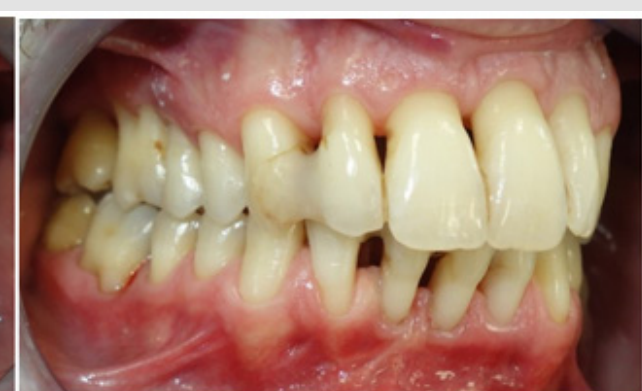

Figure 13

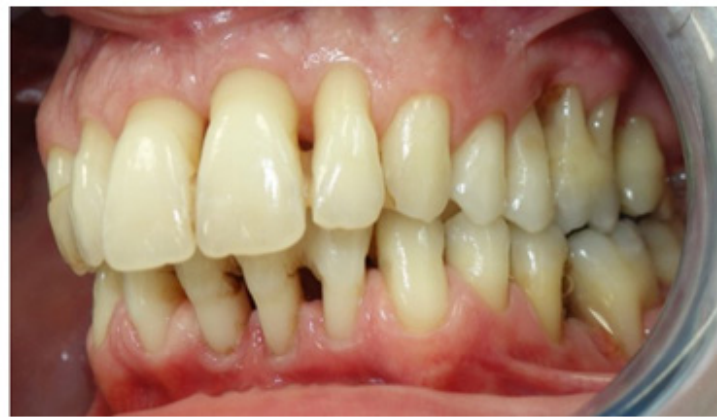

Figure 14

Figure 12 - 14: Condition of the patient after complete periodontal and maxillofacial treatment, after tooth grinding, May 2020.

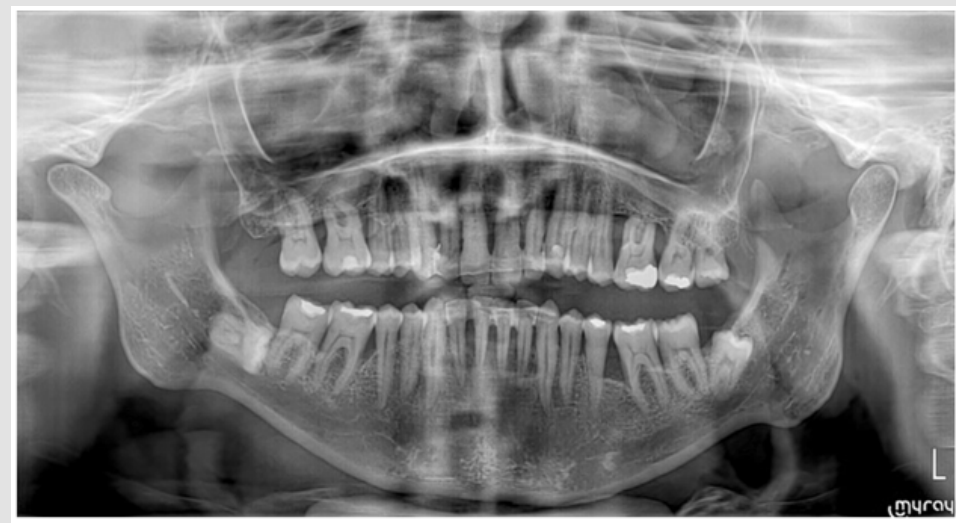

Figure 15: The patient's condition on OPG after complete periodontal and maxillofacial treatment, after tooth grinding, May 2020. 


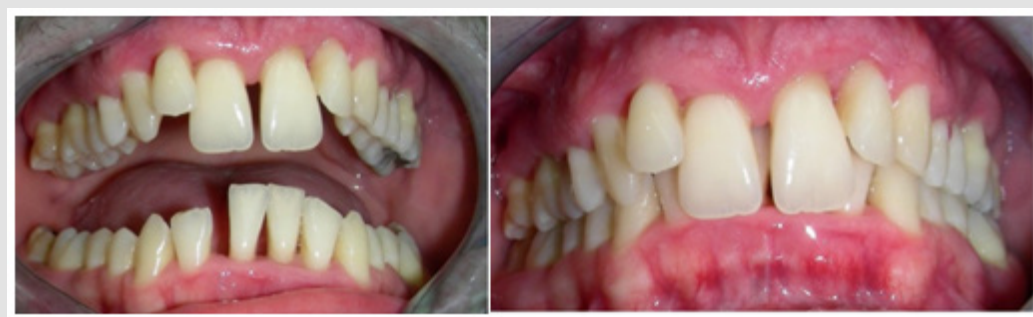

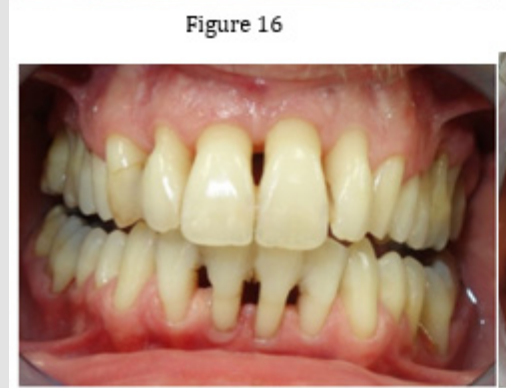

Figure 18

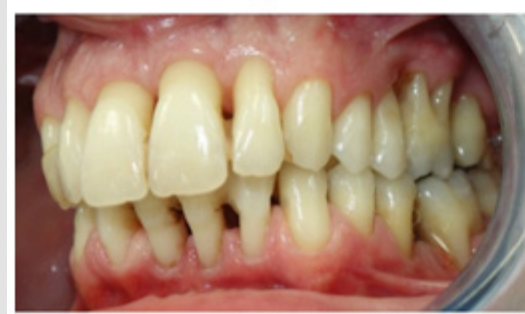

Figure 20
Figure 17

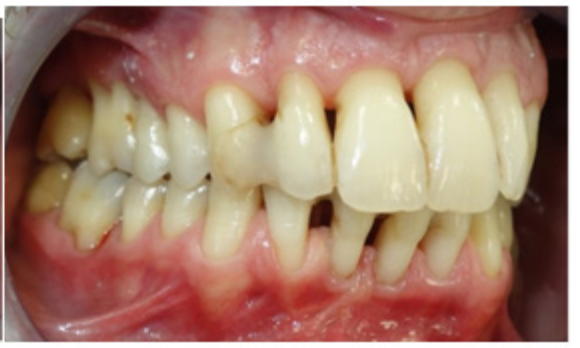

Figure 19

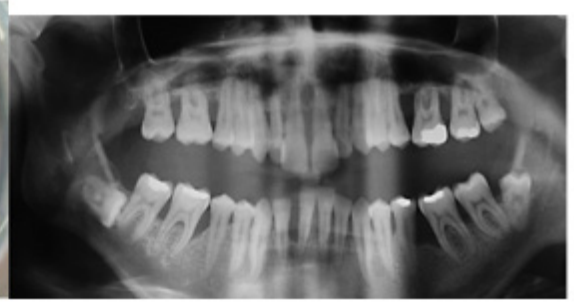

Figure 21

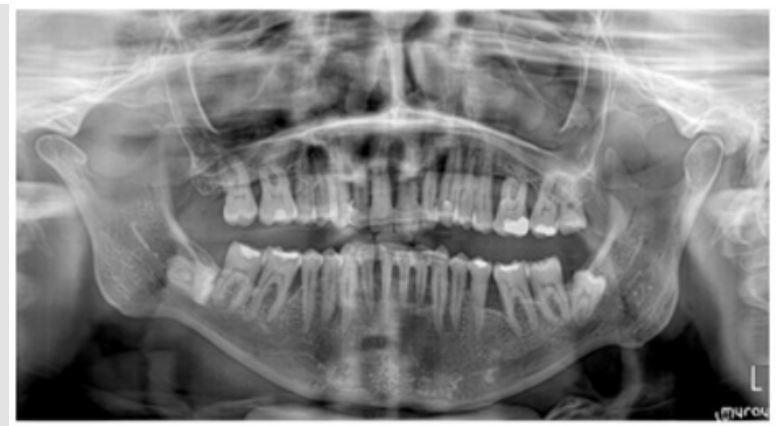

Figure 22

Figure 16 - 22: Comparison of the patient's condition before and after treatment of periodontitis and orthodontic treatment (November 2017 - May 2020).

\section{Conclusion}

A patient with a treated periodontium can undergo jaworthopedic treatment at virtually any age, provided that the inflammatory response is suppressed. The patient must have a periodontium treated and it is recommended that alveolar bone resorption not exceed $2 / 3$ of the root length. However, a longer duration of treatment should be taken into account, as the time to initiate the tissue processes necessary for this treatment increases in old age.

\section{Conflict of Interest}

No conflict of interest

\section{References}

1. ANDRAŠČÍKOVÁ L’ (2018) Význam orálneho mikrobiómu pri zabezpečení celkového zdravia človeka. In Nové trendy vo vzdelávaní a praxi zdravotníckych pracovníkov. Zborník odborných a vedeckých prác. Ružomberok: Katolícka univerzita v Ružomberku, Fakulta zdravotníctva, s. $184-190$.

2. Arpita R, JL Swetha, MR Babu, R Sudhir (2012) Recent trends in nonsurgical periodontal care for the general dentist. A review. Bangla J Dent Res Educ 4: 78-82.

3. Parikh H, Agrawal C (2019) Tri immunophasic periodontal therapy. World J Adv Sci Res 2: 192-198

4. Kumar PY, Kalaivani V (2016) Tri immunophasic periodontal therapy. World J Pharm Res 5: 356-360.

5. Matuševská M (2017) Anatómia pre dentálnu hygiene ISBN:978-80967145-6-8. 
6. Matuševská M (2017) The influence of dental hygiene on anatomical structures of the periodontium under orthodontic treatment. Rev Arg de Anat Clin 9: (2).

ISSN: 2574-1241

DOI: $10.26717 /$ BJSTR.2020.28.004708

Eva Koval'ová. Biomed J Sci \& Tech Res

(C) This work is licensed under Creative Submission Link: https://biomedres.us/submit-manuscript.php
7. Matuševská M, Rozprávková M, Lovászová K (2017) Topografická anatómia pre použitie dočasne kotviacich zariadení u pacientov s fixným ortodontickým aparátom. Stomatológ, XXVII: 2. 